EVALUASI, 3(1), Maret 2019, ISSN 2580-3387 (print) |ISSN 2615-2886 (online)

Homepage : http://e-journal.staima-alhikam.ac.id/index.php/evaluasi

DOI $\quad$ : http://doi.org/10.32478/evaluasi.v3i1.228

Article type : Original Research Article

\title{
IMPLEMENTASI MANAJEMEN BERBASIS MADRASAH DALAM PENINGKATAN MUTU MADRASAH (STUDI KASUS DI MI MAARIF GONDOSULI MUNTILAN)
}

\author{
Lailatul Munawwaroh \& Fitratul Isma \\ Mahasiswa Magister PGMI 2017 \\ UIN Sunan Kalijaga Yogyakarta
}

\begin{abstract}
:
The implementation of School-Based Management is still in a meaningful transition phase. This happened due to the unfamiliarity of school-based education management concepts in the school environment. It is not easy to implement management innovation in a short time, but the phenomenon that shows that the desire to make changes in the management sector of school management has affected the system of managing education towards School-Based Management by leaving conventional management. This study aims to determine the implementation of MBM in MI Ma'arif Gondosuli. Then there is cooperation with and regular meetings with committees every minute or thirty-five days. Meetings with student guardians, namely at the beginning of each new school year, after PTS and PAS, and specifically for sixth graders on Fridays. Evaluating the supervision of academic management carried out by the school principal and school supervisor in a planned manner and learning evaluation carried out by class teachers and subject teachers, The implementation of the development of teaching staff was carried out by the mini Teacher Working Group (KKG) meeting at the school. Planning for the development of educational facilities and infrastructure include: 1) Propose additional facilities and infrastructure, 2) Carry out maintenance on available facilities and infrastructure. Planning for funding and school finance development includes: 1) Preparation of Madrasah Work Plans and Budgets (RKAM) involving school people, 2) Making proposals to increase school operational costs, 3) Making accountability reports on the use of school budgets, 4) Administration of school finance usage.
\end{abstract}

Keywords: Implementation, Management, based, School

Abstrak:

Pelaksanaan Manajemen Berbasis Sekolah, sampai saat ini masih mengalami kendala yang berarti. Hal ini terjadi disebabkan karena belum familiarnya konsep-konsep manajemen pendidikan berbasis sekolah dilingkungan persekolahan. Tidaklah mudah menerapkan inovasi manajemen

Email address: laelapgmi@gmail.com \& fitrapipit48@gmail.com

EVALUASI: Jurnal Manajemen Pendidikan is licensed under

The CC BY License (https://creativecommons.org/licenses/by-sa/4.0/) 
dalam waktu yang singkat, namun fenomena yang terlihat menunjukkan bahwa keinginan untuk melakukan perubahan di sektor pengelolaan manajemen persekolahan telah mempengaruhi sistem penyelenggaraan pengelolaan pendidikan kearah Manajemen Berbasis Madrasah dengan meninggalkan pengelolaan manajemen yang konvesional. Penelitian ini bertujuan untuk mengetahui implementasi MBM di MI Ma'arif Gondosuli. Penelitian ini menggunakan desain penelitian deskriptif dengan pendekatan kualitatif dengan teknik pengambilan data wawancara, dokumentasi dan observasi. Teknik analisis data yakni dengan reduksi, verifikasi dan penyajian data. Lokasi penelitian yakni di MI Ma'arif Gondosuli Muntilan. Hasil penelitian menunjukkan kegiatan MBM di awali dengan perumusan Visi dan Misi Madrasah oleh para tim pengembang. Pertemuan dengan wali murid yakni setiap awal tahun ajaran baru, setelah PTS dan PAS, dan khusus untuk wali murid kelas enam setiap hari Jumat. Melakukan evaluasi supervisi pengelolaan akademik. Perencanaan pengembangan sarana dan prasarana pendidikan di antaranya: 1) Mengusulkan penambahan sarana dan prasarana, 2) Melaksanakan perawatan terhadap saran dan prasarana yang tersedia. Perencanaan pengembangan pembiayaan dan keuangan sekolah di antaranya: 1) Penyusunan Rencana Kerja dan Anggaran Madrasah (RKAM) dengan melibatkan warga sekolah, 2) Membuat usulan penambahan biaya operasional sekolah, 3) Membuat laporan pertanggungjawaban penggunaan anggaran sekolah, 4) Penyusunan administrasi penggunaan keuangan sekolah.

\section{Kata kunci: Implementasi, Manajemen, Berbasis, Madrasah}

\section{A. PENDAhuluan}

Pendidikan merupakan faktor utama dalam pembentukan pribadi manusia. Pendidikan sangat berperan dalam membentuk baik atau buruknya pribadi manusia. Sebagaimana dikemukakan dalam ${ }^{1}$ pada bab II pasal 3 menyebutkan bahwa:

"Pendidikan nasional berfungsi mengembangkan kemampuan dan membentuk watak serta peradaban bangsa yang bermatabat dalam rangka mencerdaskan kehidupan bangsa bertujuan untuk berkembangnya potensi peserta didik agar menjadi manusia yang beriman dan berwatak kepada Tuhan yang maha esa, berakhlak mulia, sehat, berilmu, cakap, kreatif, mandiri, dan menjadi warga Negara yang demokratis serta bertanggung jawab".

\footnotetext{
${ }^{1}$ Sistem Pendidikan Nasional (Indonesia, 2003). 
Dengan demikian pendidikan nasional akan dapat membentuk kepribadian peserta didik sekaligus dapat mengembangkan kemampuan serta dapat meningkatkan kualitas kehidupan dan martabat bangsa Indonesia dalam rangka mewujudkan tujuan pendidikan nasional. Namun disisi lain, pendidikan di Indonesia menunjukkan hasil yang sangat yang buruk serta mendapatkan peringkat rendah yaitu 64 dari 65 negara. Hal tersebut disampaikan oleh Kemendikbud sebagai berikut ${ }^{2}$.

Pendidikan di Indonesia masuk dalam peringkat 64, dari 65 negara yang dikeluarkan oleh lembaga Programme for International Study Assesment (PISA), pada tahun 2012. Anies mengatakan, tren kinerja pendidikan Indonesia pada pemetaan PISA pada tahun 2000, 2003, 2006, 2019 dan 2012, cenderung stagnan.

Salah satu hal yang berperan dalam meningkatkan mutu pendidikan yakni sekolah atau madrasah. Sekolah adalah lembaga yang bersifat kompleks dan unik. Bersifat kompleks karena sekolah sebagai organisasi di dalamnya terdapat berbagai dimensi yang satu sama lain saling berkaitan dan saling menentukan. Sedang sifat unik, menunjukan bahwa sekolah sebagai organisasi memiliki ciri-ciri tertentu yang tidak dimiliki oleh organisasiorganisasi lain. Ciri-ciri yang menempatkan sekolah memiliki karakter tersendiri, di mana terjadi proses belajar mengajar, tempat terselenggaranya pembudayaan kehidupan umat manusia.

Hal tersebut juga dapat ditentukan oleh operasionalisasi manajemen ditingkat sekolah. Peran utama dalam menjalankan pola manajemen sekolah terletak pada kepala sekolah dan seluruh komunitas sekolah, baik secara bersama-sama maupun individu. Kepala sekolah adalah orang yang bertanggung jawab untuk menjalankan roda organisasi sekolah. Kepala sekolah sebagai pemimpin juga harus memperhatikan pengembangan manajemen madrasah. Dengan adanya manajemen yang baik, sekolah harus mengutamakan mutu dan perlu melihat peluang pasar artinya bahwa suatu organisasi sekolah harus dapat menyesuaikan diri dengan kebutuhan konsumennya (pasar). Penyesuaian tersebut sangat perlu dilakukan, sehingga organisasi tersebut dapat bergerak maju dengan tetap mengadakan berbagai modifikasi struktur, proses dan perilaku dalam organisasinya.

Pelimpahan wewenang dari pemerintah pusat kepada daerah untuk membuat keputusan manajemen dan menyusun perencanaan sendiri dalam

\footnotetext{
${ }^{2}$ Anies Baswedan, Anies Baswedan sebut Indonesia Gawat Darurat <http://edukasi.kompas.com/read/2014/12/01/13455441/anies.baswedan.sebut.pendidi kan.indonesia.gawat.darurat,>.
} 
mengatasi masalah pendidikan dengan mengacu kepada sistem pendidikan nasional. Secara operasional desentralisasi dimulai dari 1 Januari 2001. Ruang lingkup desentralisasi manajemen pendidikan: (1) perundang-undangan pendidikan,(2) struktur organisasi pendidikan, (3) pengembangan kurikulum pendidikan, (4) profesionalisasi tenaga kependidikan, (5) sarana dan prasarana pendidikan, (6) pembiayaan pendidikan.

Undang-Undang ${ }^{3}$ pasal 51 ayat (1) yang berbunyi: "pengelolaan satuan pendidikan anak usia dini, pendidikan dasar, dan pendidikan menengah dilaksanakan berdasarkan standar pelayanan minimal dengan prinsip manajemen berbasis sekolah".

Pelaksanaan Manajemen Berbasis Sekolah, sampai saat ini masih mengalami kendala yang berarti. Hal ini terjadi disebabkan karena belum familiarnya konsep-konsep manajemen pendidikan berbasis sekolah dijajaran persekolahan. Tidaklah mudah menerapkan inovasi manajemen dalam waktu yang singkat, namun fenomena yang terlihat menunjukkan bahwa keinginan untuk melakukan perubahan di sektor pengelolaan manajemen persekolahan telah mempengaruhi sistem penyelenggaraan pengelolaan pendidikan kearah Manajemen Berbasis Sekolah dengan meninggalkan pengelolaan manajemen yang konvesional. Oleh karena itu penelitian ini di beri judul: "Pelaksanaan Manajemen Berbasis Madrasah dalam peningkatan mutu pendidikan (Studi Kasus di MI Maarif Gondosuli Muntilan)".

Rumusan masalah disini membahas tentang peningkatan mutu pendidikan melalui pengelolaan manajemen berbasis sekolah, mulai dari perencanaan, pelaksanaan, evaluasi dan faktor pendukung serta faktor penghambat peningkatan mutu pendidikan pada Madrasah Ibtidaiyah Maarif Gondosuli Muntilan.

\section{B. METODE PENELITIAN}

Penelitian ini menggunakan desain penelitian deskriptif dengan pendekatan kualitatif. Pendekatan ini dipilih berdasarkan kesesuaian antara data yang diteliti dengan karakteristik penelitian kualitatif. Penelitian kualitatif bertujuan untuk mendeskripsikan suatu fenomena dengan teori tertentu dalam bentuk verbal ${ }^{4}$. Data dalam penelitian ini berupa pada kegiatan Manajemen Berbasis Madrasah di MI Maarif Gondosuli Muntilan. Sumber data dalam penelitian ini adalah kegiatan siswa, kepala madrasah, guru, wali murid dan komite madrasah.

\footnotetext{
${ }^{3}$ Sistem Pendidikan Nasional.

${ }^{4}$ Sugiyono, Metode Penelitian Kuantitatif Kualitatif dan $R \& D$ (Bandung: Alfabeta, 2012).
} 
Instrumen yang digunakan adalah dokumen, wawancara, dan observasi. Pedoman studi dokumen digunakan untuk mengumpulkan data terkait kegiatan manajemen berbasis madrasah. Pedoman wawancara dan pedoman observasi digunakan untuk mengumpulkan data terkait manajamen berbasis madrasah. Teknik pengumpulan data dilakukan dengan tiga cara, yaitu melalui studi dokumen, wawancara, dan observasi. Wujud data berupa hasil analisis kegiatan manajemen berbasis madrasah.

Analisis data dilaksanakan secara bertahap ${ }^{5}$. Pertama, reduksi data. Data yang direduksi berasal dari hasil studi dokumentasi, hasil wawancara, dan hasil observasi. Data yang diperoleh kemudian ditentukan pola kegiatan MBS di lingkungan sekolah. Kedua, penyajian data. Data yang diperoleh berdasarkan masing-masing pola kegiatan literasi dipaparkan dalam bentuk deskriptif sehingga diperoleh deskripsi yang jelas dan sistematis. Ketiga, verifkasi data. Verifkasi data dilaksanakan dengan cara menyimpulkan data terkait fokus penelitian disertai bukti yang valid dan konsisten. Penelitian dilaksanakan di MI Maarif Gondosuli Muntilan.

\section{HASIL DAN PEMBAHASAN}

Bab ini akan menguraikan hasil penelitian serta pembahasan yang meliputi analisis dan membandingkan dengan teori-teori yang relevan yang berkenaan dengan (1) Perencanaan program peningkatan mutu pendidikan pada MI Maarif Gondosuli Muntilan; (2) Pelaksanaan program peningkatan mutu pendidikan pada pada MI Maarif Gondosuli Muntilan; (3) Evaluasi peningkatan mutu pendidikan pada pada MI Maarif Gondosuli Muntilan; (4) Faktor pendukung dan faktor penghambat pelaksanaan peningkatan mutu pendidikan pada pada MI Maarif Gondosuli Muntilan.

Manajemen: pengelolaan, proses menggunakan sumber daya secara efektif untuk mencapai sasaran. Berbasis: berdasarkan, berasaskan. Sekolah: lembaga pendidikan, lembaga belajar dan mengajar. Madrasah: sekolah yang berciri khas Islam ${ }^{6}$.

MBS/MBM merupakan salah satu bentuk desentralisasi pendidikan yang diterapkan dimasing-masing sekolah sebagai pelaksana untuk mengembangkan diri sesuai dengan otoritas yang dimiliki. MBS/MBM merupakan bentuk otonomi pendidikan yang memberikan otonomi luas kepada sekolah/madrasah dalam rangka efektifitas, efisiensi, dan produktifitas untuk peningkatan mutu ${ }^{7}$.

\section{${ }^{5}$ Sugiyono.}

${ }^{6}$ Mulyono, Manajemen Administrasi dan Organisasi Pendidikan (Yogyakarta: ArRuzz Media, 2008).

${ }^{7}$ Husaini Usman, Manajemen (Teori Praktik \& Riset Pendidikan) (Jakarta: PT. Bumi Aksara, 2008). 
Pelimpahan wewenang dari pemerintah pusat kepada daerah untuk membuat keputusan manajemen dan menyusun perencanaan sendiri dalam mengatasi masalah pendidikan dengan mengacu kepada sistem pendidikan nasional. Secara operasional desentralisasi dimulai dari 1 Januari 2001. Ruang lingkup desentralisasi manajemen pendidikan: (1) perundang-undangan pendidikan,(2) struktur organisasi pendidikan, (3) pengembangan kurikulum pendidikan, (4) profesionalisasi tenaga kependidikan, (5) sarana dan prasarana pendidikan, (6) pembiayaan pendidikan.

Undang-Undang Nomor 20 tahun 2003 tentang Sistem Pendidikan Nasional pasal 51 ayat (1) yang berbunyi: "pengelolaan satuan pendidikan anak usia dini, pendidikan dasar, dan pendidikan menengah dilaksanakan berdasarkan standar pelayanan minimal dengan prinsip manajemen berbasis sekolah".

Cikal bakal MBS adalah perjuangan guru-guru untuk memperbaiki nasib di Amerika Serikat. Tahun 1857 dibentuk Asosiasi Pendidikan Nasional (National Education Association, NEA). Tahun 1887 guru-guru New York juga mendirikan asosiasi yang sama tepatnya di Chicago. Tahun 1903 dibentuk Asosiasi Guru-Guru Philadelphia (Philadelphia Teachers Association). Di Atlanta dibentuk Persatuan Guru-Guru Sekolah Publik Atlanta. Guru-guru Leaque yang dipelopori Henry Liville, Jhon Dewey, dan Suffrajist Charlotte Perkins Gilman membentuk asosiasi yang bertujuan memberi pilihan bagi guru dalam menentukan kebijakan sekolah. Prakarsa MBS di Amerika Serikat menurut Bailey di Amerika Serikat dari tahun 1960-an hingga tahun 1990-an telah berjalan empat generasi reformasi manajemen pendidikan. Empat Generasi tersebut adalah: The New Progressive Era (tahun 1960-an), School Effectiveness Studies (tahun 1970-an), National Report (1980-an), dan Public School by Choice (sosok sekolah abad 21). Tahun 1999/2000, peluncuran dana BOMM (Bantuan Operasional Manajemen Mutu) yang langsung disetor ke rekening sekolah. Tahun 2003 khusus untuk SLTP BOMM diubah namanya menjadi Dana Rintisan untuk MPMBS (Manajemen Peningkatan Mutu Berbasis Sekolah). Terminologi MBS dimuat dalam Undang-Undang Nomor 25 tahun 2000 tentang Propenas. MBS dimaksudkan sebagai upaya peningkatan kemandirian sekolah dalam penyelenggaraan pendidikan.

\section{Tujuan MBS}

Manajamen Berbasis Sekolah mempunyai tujuan sebagai berikut ${ }^{8}$ :

a. Meningkatkan efisiensi, mutu, dan pemerataan pendidikan;

${ }^{8}$ Mulyono. 
b. Peningkatan efisiensi antara lain diperoleh melalui keleluasaan mengelola sumber daya partisipasi masyarakat dan penyederhanaan birokrasi;

c. Peningkatan mutu antara lain diperoleh melalui revitalisasi partisipasi orang tua terhadap madrasah, fleksibilitas pengelolaan madrasah dan pembelajaran, serta peningkatan profesionalisme guru dan kepala sekolah;

d. Peningkatan pemerataan diperoleh melalui peningkatan partisipasi masyarakat yang memungkinkan pemerintah lebih berkonsentrasi pada kelompok tertentu;

e. Meningkatkan kepedulian warga sekolah dan masyarakat dalam penyelenggaraan pendidikan melalui pengambilan keputusan bersama;

f. Meningkatkan tanggung jawab sekolah kepada orang tua, sekolah dan pemerintah tentang mutu sekolah;

g. Meningkatkan kompetisi yang sehat antar sekolah untuk pencapaian mutu pendidikan yang diharapkan;

h. Memberdayakan potensi sekolah yang ada agar menghasilkan lulusan yang berhasil guna dan berdaya guna.

\section{Manfaat MBS}

Dengan menerapkan Manajemen Berbasis Sekolah dapat diperoleh beberapa manfaat yakni ${ }^{9}$ :

a. Sekolah dapat mengoptimalkan sumber daya yang tersedia untuk memajukan sekolahnya;

b. Sekolah lebih mengetahui kebutuhan lembaganya khususnya input dan output pendidikan yang akan dikembangkan dan didayagunakan dalam proses pendidikan sesuai dengan tingkat perkembangan dan kebutuhan peserta didik;

c. Pengambilan keputusan partisipatif yang dilakukan dapat memenuhi kebutuhan sekolah karena sekolah lebih tahu apa yang terbaik bagi sekolahnya;

d. Penggunaan sumber daya pendidikan lebih efisien dan efektif apabila masyarakat turut serta mengawasi;

e. Keterlibatan warga sekolah dalam pengambilan keputusan sekolah yang menciptakan transparansi dan demokrasi yang sehat;

f. Sekolah bertanggung jawab tentang mutu pendidikan di sekolahnya kepada pemerintah, orang tua, peserta didik, dan masyarakat;

g. Sekolah dapat bersaing dengan sehat meningkatkan mutu pendidikan;

${ }^{9}$ Mulyono. 
h. Sekolah dapat merespons aspirasi masyarakat yang berubah dengan pendekatan yang tepat dan cepat.

\section{Komponen-Komponen MBS}

a. Manajemen Berbasis Sekolah/ Madrasah (MBS/MBM);

b. Peran Serta Masyarakat (PSM);

c. Peningkatan mutu kegiatan belajar mengajar melalui peningkatan mutu pembelajaran yang disebut pembelajaran aktif, kreatif, efektif dan menyenangkan (PAKEM) dan pembelajaran kontekstual . Komponen-Komponen MBS/MBM menurut Dadang Dally, yaitu:

a. Manajemen

1) Menyediakan manajemen/organisasi kepemimpinan sekolah;

2) Menyusun rencana sekolah dan merumuskan kebijakan;

3) Mengelola operasional sekolah;

4) Menjamin adanya komunikasi yang efektif antara sekolah dan masyarakat terkait (school community);

5) Mendorong partisipasi masyarakat;

6) Menjamin terpeliharanya sekolah yang akuntabel.

Kegiatan di madrasah yang muncul yakni madrasah mengawali dengan merumuskan VISI dan MISI madrasah guna mencapai tujuan yang diinginkan dalam madrasah. Dimana hal tersebut dirumuskan oleh tim pengembang madrasah yang terdiri dari dewan guru, kepala madrasah dan dewan komite, visi dan misi merupakan hal yang sangat dominan demi tercapainya tujuan pendidikan yang diinginkan.

Madrasah juga menyusun rencana kerja madrasah satu tahun dan rencana kerja madrasah empat tahun yang dinyatakan dalam Rencana Kerja dan Anggaran Madrasah (RKAM) rencana kerja tahunan dijadikan dasar pengelolaan madrasah yang ditujukan dengan kemandirian, kemitraan, partisipasi, keterbukaan dan akuntabilitas. Rencana kerja tahunan memuat tentang rencana pengembangan kurikulum dan pembelajaran, rencana pengembangan pendidik dan tenaga kependidikan, rencana pengembangan sarana dan prasarana, keuangan dan pembiayaan, rencana pengembangan kesiswaan, rencana pengembangan budaya dan lingkungan sekolah, rencana pengembangan partisipasi/peran serta masyarakat dan kemitraan, serta rencana-rencana kerja lain yang mengarah pada peningkatan mutu pendidikan seperti pernyataan standar pengelolaan nasional pendidikan. Perencanaan pengembangan kurikulum dan pembelajaran di antaranya 1) Penyusunan 
Kurikulum Tingkat Satuan Pendidikan (KTSP), 2) Penyusunan perangkat pembelajaran berupa program tahunan, program semester, silabus dan Rencana Pelaksanaan Pembelajaran (RPP) untuk semua mata pelajaran, 3) Penyusunan kalender pendidikan, 4) Penyusunan jadwal pembelajaran, 5) Penyusunan kurikulum muatan lokal, 6) Penyusunan program supervisi sekolah.

Perencanaan pengembangan partisipasi/peran serta masyarakat di antaranya: 1) Mengadakan pertemuan dengan orang tua siswa dalam rangka meningkatkan kerjasama sekolah dengan orang tua siswa untuk meningkatkan prestasi siswa, adapun pertemuan yang dilakukan yakni setiap setelah PTS dan PAS, kegiatan awal tahun pelajaran dan semester. Adapun untuk kelas enam pertemuan dengan orang tua murid lebih intens yakni setiap hari jumat untuk menyampaikan hasil belajar siswa dan sekaligus melakukan mujahadah atau doa untuk persiapan menjelang Ujian Berstandar Nasional (USBN) 2) Menyusun rencana pertemuan dengan komite sekolah dalam rangka meningkatkan peran komite sekolah di antaranya advisory agency, mediator agency, supporting agency dan controlling agency. Anggota komite dimadrasah terdiri dari tokoh yang berpengaruh didesa Gondosuli, para sesepuh, wali murid dan dewan guru yang berjumlah kurang lebih 30 anggota. Pertemuan komite rutin dilakukan setiap Jumat Pon, untuk membahas hal-hal yang berhubungan dengan perkembangan dan kendala madrasah setiap bulannya.

Selain itu partisipasi masyarakat dan wali murid juga tampak dengan adanya kontribusi Barisan Ansor Serba Guna setiap pagi yang membantu para dewan guru, wali murid dan peserta didik dalam mengatur lalu lintas dan keamanan di jalan setiap pagi dengan jumlah anggotanya setiap pagi sekitar tiga sampai empat anggota BANSER yang bertugas.

Program baru yang sedang digalakkan baru-baru ini adalah kegiatan wirausaha yang pengelolaannya dilakukan oleh guru dan kerjasama dengan wali murid dalam hal pengadaan jajanan atau snack yang dibuat secara higenies oleh mereka kemudian dijual di madrasah dengan tujuan supaya membantu perekonomian wali murid serta mengadakan kantin yang sehat untuk peserta didik. 


\section{b. Proses Belajar Mengajar (PBM)}

1) Meningkatkan mutu belajar siswa;

2) Menyusun kurikulum yang cocok dan tanggap terhadap kebutuhan para siswa;

3) Menawarkan pengajaran yang efektif;

4) Menyediakan program pengembangan pribadi siswa

Perencanaan pengembangan kesiswaan di antaranya: 1) Membuat persiapan penerimaan siswa baru seperti membuat surat keputusan dari kepala sekolah dan pembentukan panitia penerima siswa baru, pembentukan panitia PPDB sudah dimulai sejak masuk semester genap guna persiapan yang lebih matang serta menyiapkan acara bersama rekan dan rekanita IPNU/IPPNU yakni gebyar ceria, acara lomba antar RA dan TK guna menarik minat peserta didik baru, yang meliputi lomba menggambar, adzan, hafalan doa-doa, d.I.I; 2) Menyusun rencana kegiatan ekstrakurikuler dan pengembangan diri siswa, adapun kegiatan pengembangan diri yang ada adalah ekstrakulikuler Marching Band yang dilaksanakan setiap hari Selasa, Pramuka setiap hari Rabu, Tilawah, Pencak Silat dan Hadrah yang diikuti oleh peserta didik kelas tiga sampai lima; 3 ) Menyusun rencana melaksanakan bimbingan belajar untuk seluruh siswa untuk peningkatan prestasi akademik. Bimbingan dilakukan terhadap peserta didik yang masih lamban dalam mengikuti kegiatan belajar mengajar dengan diberi tambahan alokasi waktu dan kegiatan bimbingan untuk anak yang mempunyai bakat-bakat terpendam lainnya semisal pidato, membaca puisi, menggambar, menyanyi, melukis dan sebagainya.

Perencanaan pengembangan lingkungan dan kultur sekolah di antaranya, menyusun program unggulan yang menjadi ciri khas sekolah dalam meningkatkan dan menyalurkan potensi siswa agar lahir siswa unggul dalam berbagai prestasi, program unggulannya antara lain Shalat Duha, hafalan Asmaul Husna setiap pagi dan membaca Al-Quran setiap pagi .

Selanjutnya pelaksanaan kegiatan peningkatan mutu pendidikan meliputi: Pelaksanaan pengelolaan kurikulum tingkat satuan pendidikan (KTSP) penyusunan Visi, Misi dan Tujuan Sekolah, penyusunan struktur dan muatan kurikulum, penetapan kalender pendidikan/akademik, menyusun silabus dan RPP. Dalam penyusunan perencanaan pembelajaran didasarkan pada Standar Isi dan Standar Kompetensi Kelulusan dan peraturan 
pelaksanaannya, sedangkan dalam pelaksanaan proses pembelajaran didasarkan pada serta Standar Proses dan Standar Penilaian. Kenyataan yang terjadi di sekolah tempat penelitian dilaksanakan masih ada mata pelajaran yang silabus dan RPP belum ditulis secara lengkap dan benar. Masih ada guru yang mengkopi paste silabus dan RPP yang ditulis oleh guru dari sekolah yang lain atau silabus yang dikeluarkan oleh BSNP

.Evaluasi supervisi pengelolaan akademik dilakukan oleh kepala sekolah dan pengawas sekolah secara terencana sesuai dengan program supervisi yang telah dipersiapkan pada awal tahun ajaran untuk melaksanakan tugas dan fungsi kepala sekolah.

Evaluasi pembelajaran dilakukan oleh guru kelas dan guru mata pelajaran, evaluasi dan penilaian pembelajaran dilakukan oleh guru berupa: Penentuan Kriteria Ketuntasan Minimal (KKM), ulangan harian dilakukan apabila satu kompetensi dasar telah selesai diajarkan, ulangan tengah semester, ulangan akhir semester, dan ulangan kenaikan kelas dan kelulusan. Hasil penelitian menunjukkan bahwa pelaksanaan ulangan harian tidak dapat terlaksana seluruhnya sesuai dengan waktu atau jadwal yang telah ditentukan oleh guru kelas atau guru mata pelajaran karena waktu yang telah dipersiapkan terserap pada kegiatan pembelajaran. Hasil penilaian dilaporkan kepada orang tua siswa melalui lembar hasil belajar siswa (Rapor) pada akhir semester ganjil dan akhir semester genap.

\section{c. Sumber Daya Manusia (SDM)}

1) Menyebarkan staf dan menempatkan personel yang dapat memenuhi kebutuhan siswa;

2) Memilih staf yang memiliki wawasan MBS/MBM;

3) Menyediakan kegiatan untuk pengembangan potensi pada semua staf;

4) Menjamin kesejahteraan staf dan siswa

.Pelaksanaan pengembangan tenaga pendidik dilakukan dengan kegiatan pertemuan Kelompok Kerja Guru (KKG) mini di sekolah, dan Kelompok Kerja Guru (KKG) di lingkup kecamatan satu kali dalam satu bulan. Diikuti oleh semua guru dalam gugus sekolah dibimbing oleh guru pemandu mata pelajaran. Selain kegiatan KKG, para guru juga diikutkan dalam kegiatan diklat kurikulum 2013 baik yang diselenggarakan ditingkat kecamatan, kabupaten maupun ditingkat gugus. Hal ini bertujuan untuk 
meningkatkan wawasan guru mengenai implementasi kurikulum 2013 beserta perangkat yang harus disiapkan dalam kurikulum 2013 dan hal-hal baru yang berhubungan literasi, pendidikan karakter dan HOTS.

Untuk kepala madrasah dan guru PNS juga diikutkan dalam diklat substansif kepala Madrasah oleh Balai Diklat serta kegiatan MBM atau MBS yang diadakan oleh yayasan yang berfungsi untuk meningkatkan kompetensi kepala madrasah dalam hal kompetensi manajerial, keiwrausahaan, pedagogik, sosial dan lain sebagainya.

d. Sumber Daya dan Administrasi

1) Mengidentifikasi dan mengalokasikan sumber daya sesuai dengan kebutuhan;

2) Mengelola alokasi dana sekolah;

3) Menyediakan dukungan administratif;

4) Mengelola pemeliharaan gedung dan sarana lainnya;

5) Mengatur pembahasan tentang kinerja sekolah

Perencanaan pengembangan sarana dan prasarana pendidikan di antaranya: 1) Mengusulkan penambahan sarana dan prasarana yakni dengan membuat proposal yang ditujukan ke beberapa pihak guna menunjang sarpras yang memadai, 2) Melaksanakan perawatan terhadap sarana dan prasarana yang tersedia.

Perencanaan pengembangan pembiayaan dan keuangan sekolah di antaranya: 1) Penyusunan Rencana Kerja dan Anggaran Madrasah (RKAM) dengan melibatkan warga sekolah, 2) Membuat usulan penambahan biaya operasional sekolah, 3) Membuat laporan pertanggungjawaban penggunaan anggaran sekolah yakni penggunaan dana BOS maupun BOSDA, 4) Penyusunan administrasi penggunaan keuangan sekolah baik oleh bendahara sekolah maupun bendahara BOS.

Faktor pendukung selanjutnya adalah kepala sekolah memberikan kebebasan kepada guru dalam proses pembelajaran, guru dapat menciptakan kreativitas dan inovasi dalam pembelajaran mulai dari perencanaan pembelajaran, proses pembelajaran sampai pada evaluasi pembelajaran.

Sedangkan yang menjadi faktor penghambat pelaksanaan manajemen berbasis dalam peningkatan mutu pendidikan belum semua guru dapat menjalankan kebijakan sekolah terutama pada pengelolaan pembelajaran dan penilaian pembelajaran hal tersebut dikarenakan 
pemahaman tentang pengelolaan pembelajaran dan pengelolaan sekolah masih terbatas pada pelaksanaan kewajiban, dana pendidikan yang tersedia belum mencukupi untuk pelaksanaan kebijakan manajemen berbasis sekolah dalam peningkatan mutu pendidikan. Masih ada masyarakat yang belum memiliki rasa kepedulian dan kesadaran yang tinggi terhadap pendidikan.

\section{KESIMPULAN}

Kegiatan manajemen berbasis madrasah di MI Maarif Gondosuli dengan merumuskan VISI dan MISI madrasah guna mencapai tujuan yang diinginkan dalam madrasah. Madrasah juga menyusun rencana kerja madrasah satu tahun dan rencana kerja madrasah empat tahun yang dinyatakan dalam Rencana Kerja dan Anggaran Madrasah (RKAM). Kemudian melakukan perencanaan pengembangan partisipasi/peran serta masyarakat. Melakukan evaluasi supervisi pengelolaan akademik dilakukan oleh kepala sekolah dan pengawas sekolah secara terencana sesuai dengan program supervisi yang telah dipersiapkan pada awal tahun ajaran untuk melaksanakan tugas dan fungsi kepala sekolah. Evaluasi pembelajaran dilakukan oleh guru kelas dan guru mata pelajaran,

Pelaksanaan pengembangan tenaga pendidik dilakukan dengan kegiatan pertemuan Kelompok Kerja Guru (KKG) mini di sekolah, dan Kelompok Kerja Guru (KKG) di lingkup kecamatan satu kali dalam satu bulan. Perencanaan pengembangan sarana dan prasarana pendidikan di antaranya: 1) Mengusulkan penambahan sarana dan prasarana, 2) Melaksanakan perawatan terhadap saran dan prasarana yang tersedia. Perencanaan pengembangan pembiayaan dan keuangan sekolah di antaranya: 1) Penyusunan Rencana Kerja dan Anggaran Madrasah (RKAM) dengan melibatkan warga sekolah, 2) Membuat usulan penambahan biaya operasional sekolah, 3) Membuat laporan pertanggungjawaban penggunaan anggaran sekolah, 4) Penyusunan administrasi penggunaan keuangan sekolah

Faktor pendukung selanjutnya adalah kepala sekolah memberikan kebebasan kepada guru dalam proses pembelajaran, guru dapat menciptakan kreativitas dan inovasi dalam pembelajaran mulai dari perencanaan pembelajaran, proses pembelajaran sampai pada evaluasi pembelajaran. Sedangkan yang menjadi faktor penghambat pelaksanaan manajemen berbasis dalam peningkatan mutu pendidikan belum semua guru dapat menjalankan kebijakan sekolah terutama pada pengelolaan pembelajaran dan penilaian pembelajaran hal tersebut dikarenakan pemahaman tentang 
EVALUASI, 3(1), Maret 2019, ISSN 2580-3387 (print) |ISSN 2615-2886 (online) http://doi.org/10.32478/evaluasi.v3i1.228

pengelolaan pembelajaran dan pengelolaan sekolah masih terbatas pada pelaksanaan kewajiban, dana pendidikan yang tersedia belum mencukupi untuk pelaksanaan kebijakan manajemen berbasis sekolah dalam peningkatan mutu pendidikan. Masih ada masyarakat yang belum memiliki rasa kepedulian dan kesadaran yang tinggi terhadap pendidikan.

\section{E. REFERENSI}

Anies Baswedan, Anies Baswedan sebut Indonesia Gawat Darurat <http://edukasi.kompas.com/read/2014/12/01/13455441/anies.baswe dan.sebut.pendidikan.indonesia.gawat.darurat,>

Husaini Usman, Manajemen (Teori Praktik \& Riset Pendidikan) (Jakarta: PT. Bumi Aksara, 2008)

Mulyono, Manajemen Administrasi dan Organisasi Pendidikan (Yogyakarta: Ar-Ruzz Media, 2008)

Sistem Pendidikan Nasional (Indonesia, 2003)

Sugiyono, Metode Penelitian Kuantitatif Kualitatif dan $R \& D$ (Bandung: Alfabeta, 2012) 